\title{
Cytochrome P450 Enzyme Inhibitors from Nature
}

\author{
Simone Badal, Mario Shields and Rupika Delgoda \\ University of the West Indies/ \\ Natural Products Institute
}

Jamaica

\section{Introduction}

\subsection{Cytochrome P450}

Cytochrome P450 (CYP) is a heme containing enzyme superfamily that catalyzes the oxidative biotransformation of lipophilic substrates to hydrophilic metabolites facilitating their removal from cells. The CYPs were first recognized by Martin Klingenberg (Klingenberg, 1958) while studying the spectrophotometric properties of pigments in a microsomal fraction prepared from rat livers. When a diluted microsomal preparation was reduced by sodium dithionite and exposed to carbon monoxide gas, a unique spectral absorbance band with a maximum at $450 \mathrm{~nm}$ appeared. The ferric ion in the resting heme, binds easily with $\mathrm{CO}$ following reduction, and the complex's maximal absorbance band, unique amongst hemeproteins, serves as the signature of CYP enzymes.

CYPs are mostly located in the endoplasmic reticulum, and to some extent in mitochondrial fractions of hepatic and extra-hepatic tissues. Even though these enzymes are ubiquitous in the body (Table 1), of the 18 families in mammals identified, 11 are expressed in a typical human liver (CYP1A2, CYP2A6, CYP2B6, CYP2C8/9/18/19, CYP2D6, CYP2E1, and CYP3A4/5). In addition, five of these enzymes (CYPs 1A2, 2C9, 2C19, 2 D6 and 3A4) expressed at high levels in the liver demonstrate a broad substrate selectivity which accounts for about $95 \%$ of drug metabolism (Nelson, 2009; Treasure, 2000).

The metabolism of a drug can be altered by another drug or foreign chemical and such interactions can often be clinically significant. As a result, the FDA (Food and Drug Administration) and other regulatory agencies such as the Department of Health and Human Services (DHHS), Centers for Disease Control and Prevention (CDS) and Hazard Analysis Critical Control Point (HACCP) among others expect information on the relationship between each new drug to CYP enzymes (substrate, inhibitor and or inducer) making these enzymes vital in the process of drug discovery. One of the major concerns is avoiding drug interactions, an issue whose importance increases with the aging of population (Guengerich, 2003) along with the increase in the practice of polypharmacy. 


\begin{tabular}{ll}
\hline Organ & CYPs detected \\
\hline Nasal mucosa & 2A6, 2A13, 2B6, 2C, 2J2, 3A \\
Trachea & 2A6, 2A13, 2B6, 2S1 \\
Lung & $1 \mathrm{~A} 1,1 \mathrm{~A} 2,1 \mathrm{~B} 1,2 \mathrm{~A} 6,2 \mathrm{~A} 13,2 \mathrm{~B} 6,2 \mathrm{C} 8,2 \mathrm{D} 6,2 \mathrm{E} 1,2 \mathrm{~F} 1,2 \mathrm{~J} 2,2 \mathrm{~S} 1$, \\
& $3 \mathrm{~A} 4,3 \mathrm{~A} 5,4 \mathrm{~B} 1$ \\
Oesophagus & $1 \mathrm{~A} 1,1 \mathrm{~A} 2,2 \mathrm{~A}, 2 \mathrm{E} 1,2 \mathrm{~J} 2,3 \mathrm{~A} 5$ \\
Stomach & $1 \mathrm{~A} 1,1 \mathrm{~A} 2,2 \mathrm{C}, 2 \mathrm{~J} 2,2 \mathrm{~S} 1,3 \mathrm{~A} 4$ \\
Small Intestine & $1 \mathrm{~A} 1,1 \mathrm{~B} 1,2 \mathrm{C} 9,2 \mathrm{C} 19,2 \mathrm{D} 6,2 \mathrm{E} 1,2 \mathrm{~J} 2,2 \mathrm{~S} 1,3 \mathrm{~A} 4,3 \mathrm{~A} 5$ \\
Colon & $1 \mathrm{~A} 1,1 \mathrm{~A} 2,1 \mathrm{~B} 1,2 \mathrm{~J} 2,3 \mathrm{~A} 4,3 \mathrm{~A} 5$ \\
\hline
\end{tabular}

Table 1. Human cytochrome P450 genes expressed in different parts of the respiratory and gastrointestinal tracts (adopted from Ding and Kaminsky, 2003).

\subsection{Classification of CYP enzymes}

All eukaryotic CYPs except fungal CYP55s are membrane bound; 18 mammalian CYP enzyme structures are known and 15 of these are of human origin; [1A2, 2A6, 2A13, 2B4 rabbit, 2B6, 2C5 rabbit, 2C8, 2C9, 2D6, 2E1, 2R1, 3A4, 7A1, 8A1, 19A1, 24A1 rat, 46A1, 51A1, (Nelson and Nebert, 2011)]. CYPs sharing $>40 \%$ sequence identity are categorised within the same family while those with $>55 \%$ sequence identity are placed within the same subfamily. The CYP superfamily members are named according to a nomenclature system that was established in the mid-1980s (Nebert et al., 1987), however, the last comprehensive revision was published in 1996 (Nelson et al., 1996).

CYP2 is the largest CYP450 family in mammals with 13 subfamilies and 16 genes in humans. CYPs2C8, 2C9, 2C18 and 2C19 jointly metabolise more than 50 drugs whilst CYP2D6 metabolises more than 70 drugs (Meyer and Zanger, 1997). CYP3A is the most abundantly expressed CYP450 gene in the human liver and gastrointestinal tract (Nelson, 1999) and is known to metabolise more than 120 commonly prescribed pharmaceutical agents.

CYPs1Al and 1B1 are predominately expressed in extra-hepatic tissues (Guengerich and Shimada, 1991; Shimada et al., 1992) while CYP1A2 is expressed primarily in the liver. As a result, constitutive levels of CYP1A2 are much greater than those of CYPs1A1 and 1B1 (Shimada et al., 1992; Shimada et al., 1994b) whose levels are usually induced by PAHs. All 3 members of the CYP1 family are upregulated by halogenated and polycyclic aromatic hydrocarbons such as those found in cigarette smoke and charred food.

\subsection{Importance of CYP enzyme inhibition}

\subsubsection{Involvement in drug interactions}

The metabolism of a drug can be altered by another drug or foreign chemical and such interactions can often be clinically significant. The observed induction and inhibition of CYP enzymes by various traditional remedies have led to the general acceptance that natural therapies can have adverse effects. This is contrary to the popular beliefs in countries where there is an active practice of ethnomedicine. Drug-herb interactions may involve 
competitive, noncompetitive, or uncompetitive inhibition of drug metabolizing enzymes or enzyme induction by the phytopharmaceutical (Delgoda and Westlake, 2004).

Several epidemiological surveys including ones conducted by our laboratory (Delgoda et al., 2004; Delgoda et al., 2010; Picking et al., 2011) have indicated high usage of herbal medicines along with prescription medicines with low physician awareness. With over $80 \%$ of the prescription medicine users also seeking some form of herbal remedy in Jamaica, the chances of drug interactions rises and this prompted investigations into likely pharamacokinetic, metabolism based interactions between the two types of medicines.

The CYP enzymes, responsible for the metabolism of over $90 \%$ of drugs in the market is unsurprisingly associated with numerous metabolism related drug interactions (Guengerich, 1997), including those of drugs and herbs (Ioannides, 2002; Delgoda and Westlake, 2004). The inhibition of CYP3A4 by fucocoumarins found in grapefruit juice leading to clinically observable toxicities with drugs and the induction of the same CYP3A4 enzyme by ingredients found in St. John's wort leading to subtherapeutic interferences with cycloporin provide suitable examples for the involvement of CYP enzymes in drug herb interactions. While clinical studies provide the ultimate proof for relevant drug interactions, in-vitro laboratory evaluations with CYP enzymes, has provided a convenient, economical and useful starting point for screening those herbs that may ultimately cause clinically observable drug interactions. Human liver microsomes, heterologously expressed enzymes and hepatocytes although with limitations, have provided convenient means for such initial assessements.

In this chapter, we describe for the first time, the initial inhibitory impact of four commonly consumed infusions on six major CYP enzymes. Our findings support that the teas are moderate to weak CYP inhibitors and so we postulate that they would unlikely result in drug interactions.

\subsubsection{CYP inhibition and its relation to chemoprevention}

Approximately five decades of systematic drug discovery and development have established a reliable collection of chemotherapeutic agents (Yarbro, 1992; Chabner, 1991). These chemotherapeutic agents have assisted with numerous successes in the treatment and management of human cancers (Chabner et al., 1991).

Chemoprevention is the ability of compounds to protect healthy tissues via the prevention, inhibition or reversal of caricnogenesis. The inhibition of CYP1 enzymes is one such route among others that include the induction of cell cycle arrest, the induction of phase II enzymes and the inhibition of inflammatory. The CYP1 family has been linked with the activation of pro-carcinogens which is facilitated by the regulation of the aryl hydrocarbon receptor. As such research has shown that inhibiting CYP1 enzymes plays a key role in protecting healthy cells from the harmful effects of activated carcinogens.

Among the polycyclic hydrocarbons that are activated into reactive metabolites by CYPs $1 \mathrm{~A} 1$ and $1 \mathrm{~B} 1$ is benzo-a-pyrene [BaP]. Metabolites from $\mathrm{BaP}$ include phenols, polyphenols, quinines, epoxides and dihydrodiols. Among these dihydrodiols; (-)-benzo[a]pyrene-trans7,8-dihydrodiol (BPD) and (+)-anti-benzo[a]pyrene-trans-7,8-dihydrodiol-9,10-epoxide (anti- 
BPDE) are carcinogenic, however the latter is the ultimate carcinogen as it has been shown to bind DNA predominantly at the $\mathrm{N}^{2}$-position of guanine to produce primarily $\mathrm{N}^{2}$-guanine lesions, benzo-a-pyrene 7,8-diol-9,10-epoxide-N22-deoxyguanosine (BPDE-N2-dG) adduct (Osborn et al., 1976). It is proposed that BPDE-N2-dG is linked to the high frequency of p53 $\mathrm{G} \rightarrow \mathrm{T}$ transversions observed in lung cancer of smokers (Hainaut and Pfeifer, 2001; Pfeifer et al., 2002). Further mutations in the p53 gene have also been found and these include transversions, $\mathrm{G} \rightarrow \mathrm{A}$ and $\mathrm{G} \rightarrow \mathrm{C}$ (Shukla et al., 1997; Schiltz et al., 1999). Similar to the role of CYP1A1 in the activation of $\mathrm{BaP}$ is that of the aromatic amines; amino-3-methylimidazo[4,5flquinoline (IQ), 2-amino-1-methyl-6-phenylimidazo[4,5-b]pyridine (PhIP) and 2-amino-3,8dimethylimidazo-[4,5-flquinoxaline (MeIQx). CYP1A2 plays an important role in the Noxidation of these aromatic amines which have been linked to colon and urothelium cancers (Landi et al., 1999), thus highlighting the role of CYP1 enzymes in carcinogenic activation and thus their potential as preventative targets. Fig.1 is a schematic representation of the process of carcinogenesis at the cellular level.

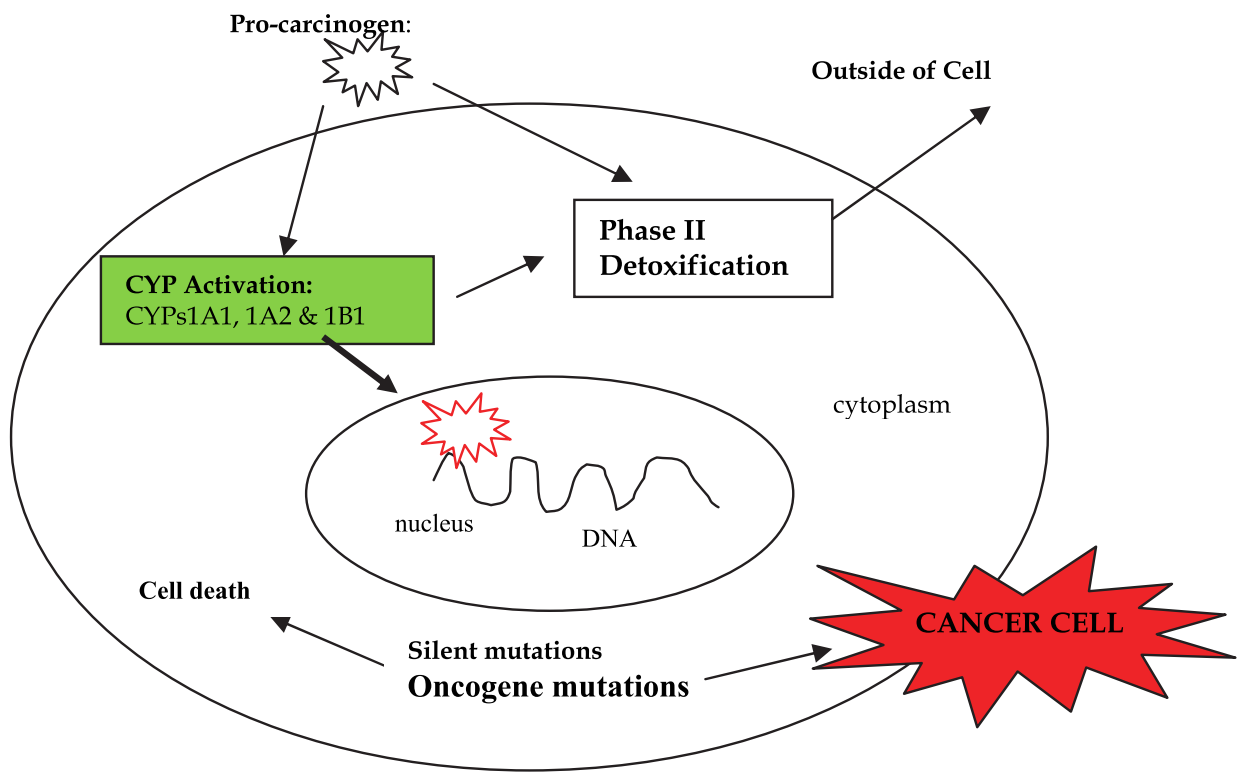

Fig. 1. A schematic representation of carcinogenesis via the activation of CYP1 enzymes. Upon the activation of the pro-carcinogens by the CYP1 enzymes, they have the ability to bind to DNA, which can lead to mutations and then the formation of cancer cells.

One of the first reported chemoprotectants was disulfiram (Stoner et al., 1997) which inhibited the action of dimethylhydrazine via the inhibition of CYP1 enzymes. Other chemopreventive agents are discussed by Chang and others (Chang et al., 2002) who report that Ginseng decreases the incidence of 7,12 dimethyldenz(a)anthracence (DMBA)-initiated tumorigenesis in mice via the inhibition of CYPs1A1, 1A2 and 1B1. Also, the flavanoid, galangin was found 
to be an agonist of the aryl hydrocarbon receptor and consequently was responsible for an increased level of CYP1A1 expression, however this effect was counteracted by its ability to inhibit the enzyme directly and so is deemed an effective chemo-preventive agent (Ciolino and Yeh, 1999). Resveratrol was also found to exhibit chemo-preventive properties via the inhibition of CYP1A1 expression in vivo by preventing the binding of the AhR to promoter sequences that regulate the CYP1A1 transcription and also by the direct potent inhibition of CYPs1A1 and 1B1 (Ciolino et al., 1998; Chen et al., 2004).

\subsection{CYP inhibition and its relation to chemoprevention}

Bioactivity of isolates from the Jamaica plants, Amyris plumieri, Peperomia amplexicaulis, Spathelia sorbifolia and Picrasma excelsa are reported in this chapter. Amyris plumieri is found in the Caribbean, Central America and Venezuela and plants of this genus have been used in folk medicine against skin irritation while isolates have been found to exhibit anticancer and antimycobacterial properties (Fuente et al., 1991, Hartwell, 1968). Even though both Peperomia amplexicaulis and Spathelia sorbifolia are not commonly consumed in Jamaica, isolates from these plants have been shown to exhibit antiprotozoal, chemopreventive and anti-cancer activity (Mota et al., 2009; Cassady et al., 1990) and previously examined for CYP inhibitions (Badal et al., 2011; Shields et al., 2009) and overviewed in this chapter. Infusions of the plant Picrasma excelsa, known as Jamaican bitterwood tea, are commonly consumed to lower blood sugar levels in diabetics who are already on prescription medicines. All other plants investigated in this chapter; Rhytidophyllum tomentosa, Psidium guajava, Symphytium officinale, Momordica charantia are frequently consumed in the form of teas or the fruits of the appropriate plants. We therefore investigated the inhibition properties of these teas against a panel of CYP450 enzymes in order to assess the potential for drug interactions with comedicated pharmaceuticals.

\section{Materials and methods}

\subsection{Chemicals}

All CYP substrates and metabolites were purchased from Gentest Corporation (Woburn, MA, U.S.A.). All other chemicals were purchased from Sigma-Aldrich (MO, U.S.A.).

\subsection{CYP microsomes}

Escherichia coli membranes expressing human CYP2D6, CYP3A4, CYP1A1, CYP1A2 and each containing P450 reductase, were a gift from Dr. Mark Paine and Prof. Roland Wolfe (University of Dundee, UK). CYP2C19 expressed in baculovirus-insect cells (supersomes) were purchased from Gentest Corporation, Woburn, MA

\subsection{Preparation of infusions from medicinal plants}

The selection of the plants for screening and method of preparation were based on the survey conducted by Delgoda et al (Delgoda et al., 2010). The teas were prepared by infusing $100 \mathrm{ml}$ of boiling deionized water per $1 \mathrm{~g}$ of dried, finely ground material (leaf, bark or wood chips), for 10 minutes. The resulting liquor was suctioned filtered through type 1 Watman 
filter paper. A portion of the filtrate was then centrifuged at $13000 \times \mathrm{g}$ for 5 minutes to remove suspended solids.

\subsection{Separation of active ingredients from medicinal plants}

Infusions were freeze dried and re-dissolved in water just prior to use, unless otherwise stated. $25 \mu \mathrm{l}$ infusions were loaded onto a microsorb C18 column (ID $4.6 \mathrm{~mm}, 25 \mathrm{~cm}, 5 \mathrm{~m}$ ) and separated using the appropriate solvent systems using Varian Prostar HPLC system (Varian Inc. USA).

\subsection{CYP inhibition assays}

Routinely, appropriate volumes of potassium phosphate buffer (KPB), test inhibitor, CYP, and the substrates were added to a NADPH regenerating mixture and made up to $400 \mu \mathrm{L}$, and monitored fluorometrically on a continuous basis for $10 \mathrm{mins}$ as described elsewhere (Shields, 2009), using CYP450 substrates,3-[2-(N,N-Diethyl-N-methylamino)ethyl]-7methoxy-4methylcoumarin (AMMC), 7-Benzyloxy-4-trifluoromethylcoumarin (BFC), as substrates for CYP3A4 and CYP2D6 respectively and 7-ethoxy-3-cyanocoumarin (CEC) as substrate for CYPs 1A1, 1A2, 2C19 and 2C9. In other instances (as specified in each case), a 96-well plate assay was employed as detailed in (Badal et al., 2011). Fluoroscence was monitored using a Varian Cary Eclipse Fluorescence spectrophotometer.

Positive control experiments were conducted with varying concentrations of furafaylline $(\geq 98 \%)(0.5-10 \mu \mathrm{M})$, quinidine $(\geq 90 \%, 1-50 \mathrm{nM})$ and ketoconazole $(\geq 98 \%)$ (2-100nM) with CYP1A2, CYP2D6 and CYP3A4 respectively.

\subsection{Data analysis}

$\mathrm{IC}_{50}$ and $\mathrm{K}_{\mathrm{i}}$ values were determined by fitting the data in Sigma Plot (version 10.0) and enzyme kinetics module, using non linear regression analysis. The data listed represent the average values from three different determinations.

\section{Results}

\subsection{Optimising experimental conditions}

To verify the accuracy of experimental techniques employed to detect CYP inhibition, assays with known inhibitors were carried out with furafylline (against CYP1A2), ketoconazole (against CYP1A1, CYP1B1 and CYP3A4), (-)-N-3-benzyl-phenobarbital (NBPB, against CYP2C19) and quinidine (against CYP2D6) and the obtained $\mathrm{IC}_{50}$ values $(0.8 \pm 0.2,0.04 \pm 0.01$, $6.3 \pm 1.7,0.06 \pm 0.01,0.3 \pm 1910.01$, and $0.03 \pm 0.01 \mu \mathrm{M}$ respectively) compared well with published values $(0.99, \mathrm{~b} 10, \mathrm{~b} 10,0.06,0.25$ and $0.01 \mu \mathrm{M}$ respectively; Shields, 2009; Badal et al., 2011; Powrie, 2010; Stresser et al., 2004; Cali, 2003 and McLaughlin et al., 2008).

\subsection{Natural products as CYP inhibitors}

Several classes of natural products were examined in our laboratory for their inhibitory properties towards CYP450 enzymes. Chromene amides (CAs) isolated from Amyris plumieri, quassinoids isolated from Picrasma excelsa, anhydrosorbifolin isolated from 
Spathelia sorbifolia and chroman 6 isolated from Peperomia amplexicaulis. Structures for these can be seen in Figs. 2.1, 2.2 and 2.3 and in addition obtained $\mathrm{IC}_{50} \mathrm{~s}$ can be seen in Table 2. Both CA1 and quassin exhibited the most potency against CYP1A1. Both Anhydrosorbifolin and chroman 6 and CAs, 1, 2 and 3moderately ( $\mathrm{IC}_{50}$ between 1 and $10 \mu \mathrm{M}$ ) inhibited the activities of CYP1 family.

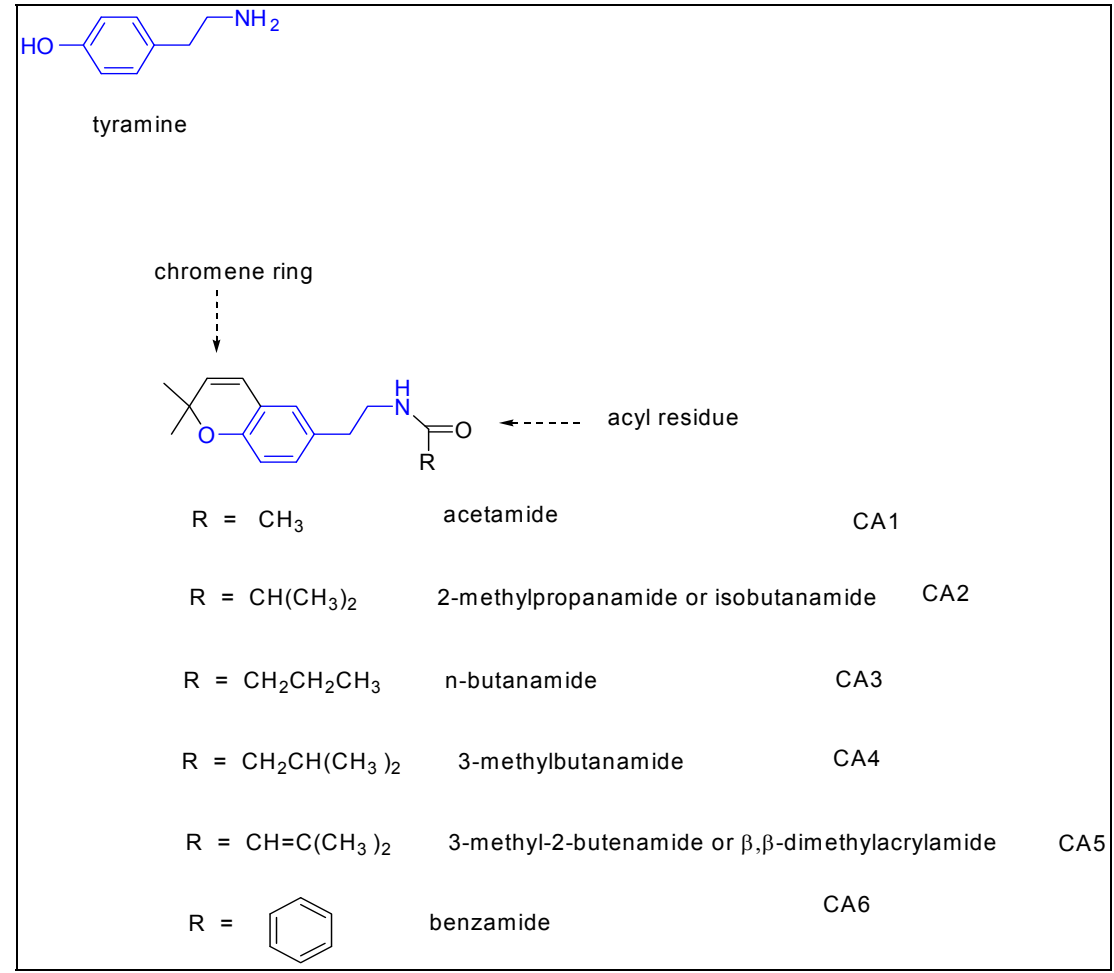

Fig. 2.1. Chromene amides

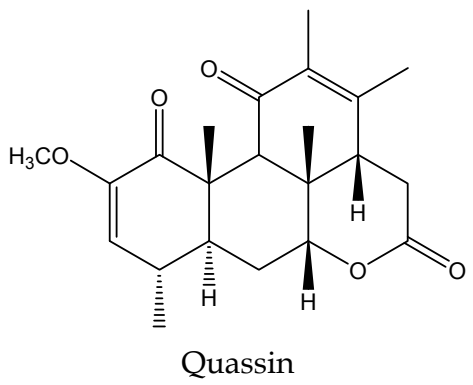

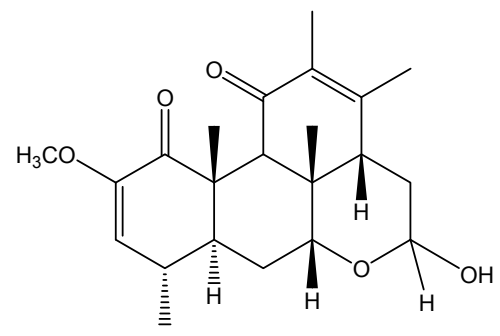

Neoquassin

Fig. 2.2. Quassinoids 


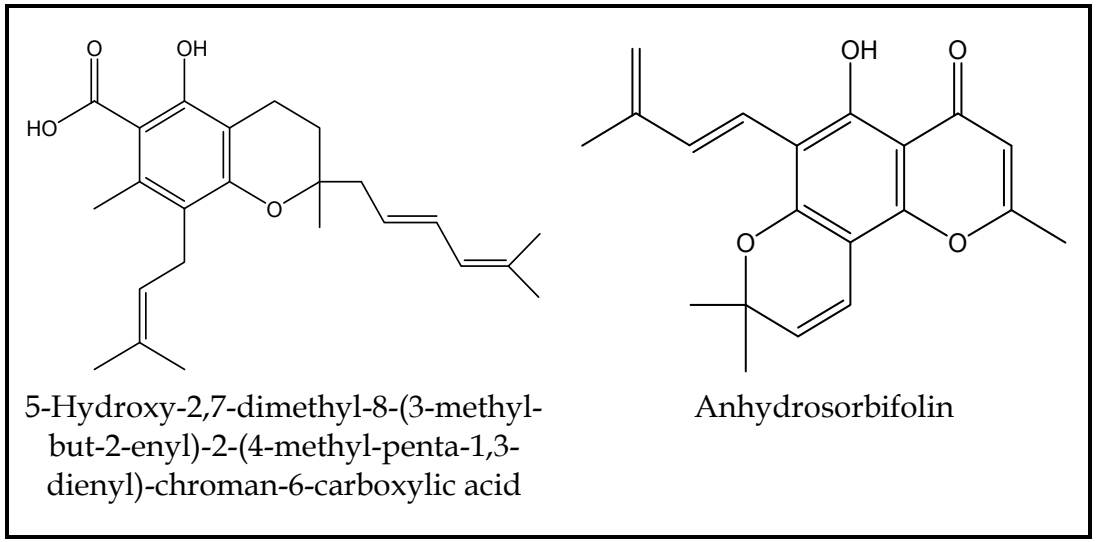

Fig. 2.3. Others

\begin{tabular}{cccccccc}
\hline Compounds & \multicolumn{7}{c}{ CYP isoforms } \\
\cline { 2 - 8 } & $1 \mathrm{~A} 1$ & $1 \mathrm{~A} 2$ & $1 \mathrm{~B} 1$ & $2 \mathrm{C} 9$ & $2 \mathrm{C} 19$ & $2 \mathrm{D} 6$ & $3 \mathrm{~A} 4$ \\
\hline CA1 & $1.31 \pm 0.42$ & $32.80 \pm$ & $15.36 \pm 0.42$ & nd & $0.77 \pm$ & $2.22 \pm$ & $1.14 \pm 0.4$ \\
& $\mathrm{~K}_{\mathrm{i}}=0.37$ & 4.45 & & & 0.39 & 0.69 & 8 \\
CA2 & $1.63 \pm 0.53$ & $6.25 \pm$ & $37.04 \pm 1.51$ & nd & $1.09 \pm$ & $359.88 \pm$ & $15.48 \pm 0$. \\
& $\mathrm{K}_{\mathrm{i}}=2.40$ & 1.85 & & & 0.52 & 144.55 & 45 \\
CA3 & $2.43 \pm 0.62$ & $189.84 \pm$ & $179.30 \pm 20.5$ & nd & $2.43 \pm$ & $11.70 \pm$ & $122.93 \pm 5$ \\
& $\mathrm{~K}_{\mathrm{i}}=1.39$ & 7.60 & & & 0.28 & 5.40 & .95 \\
CA4 & $14.39 \pm$ & $18.59 \pm$ & $18.14 \pm 1.02$ & nd & $2.55 \pm$ & $84.40 \pm$ & $7.63 \pm 1.2$ \\
& 7.40 & 0.67 & & & 1.85 & 3.5 & 6 \\
Quassin & 9.2 & 57.6 & $\mathrm{ND}$ & 92.5 & 262.5 & 217.8 & 47.0 \\
& $\mathrm{~K}_{\mathrm{i}}=10.8$ & & & & & & \\
Neoquassin & 11.9 & 85.3 & $\mathrm{ND}$ & 80.6 & 113.4 & 184.1 & 24.5 \\
& $\mathrm{~K}_{\mathrm{i}}=11.3$ & & & & & & \\
Anhydro- & 4.9 & 1.9 & 1.4 & nd & nd & nd & nd \\
sorbifolin & & & & & & & \\
Chroman 6 & 2.1 & 5.8 & 5.6 & nd & nd & nd & nd \\
\hline
\end{tabular}

Table 2. Summary of $\mathrm{IC}_{50}$ and $\mathrm{K}_{\mathrm{i}}$ values $(\mu \mathrm{M})$ obtained from the interaction of isomers of chromene amides, quassinoids along with anhydrosorbifolin and chroman 6 using heterologously expressed CYP microsomes. ND: Not determined due to intrinsic fluorescence and quenching/enhancement of the metabolite nd: not done

\subsection{Herbal infusions with CYP inhibitors}

Hot water infusions of five popular herbs; Rhytidophyllum tomentosa, Psidium guajava, Symphytium officinale, Momordica charantia and Picrasma excelsa were characterized for impact as shown in Fig. 3 and calculated $\mathrm{IC}_{50}$ values on the activities of CYP enzymes are shown in Table 3. 


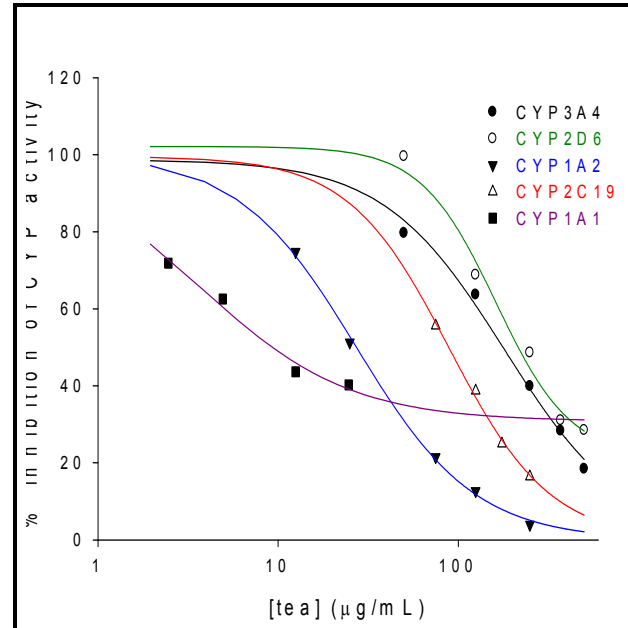

A

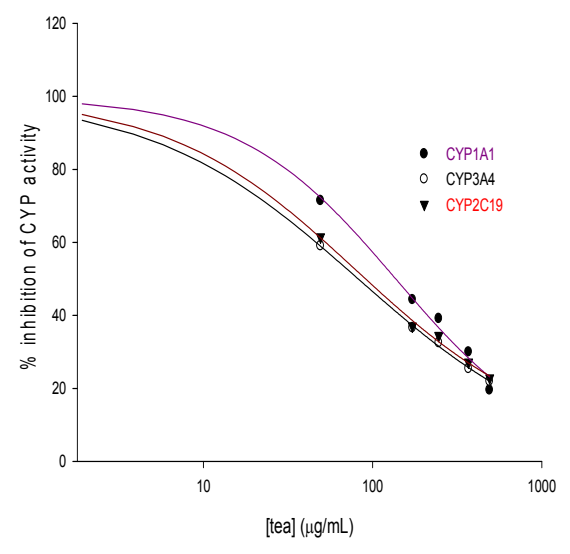

C

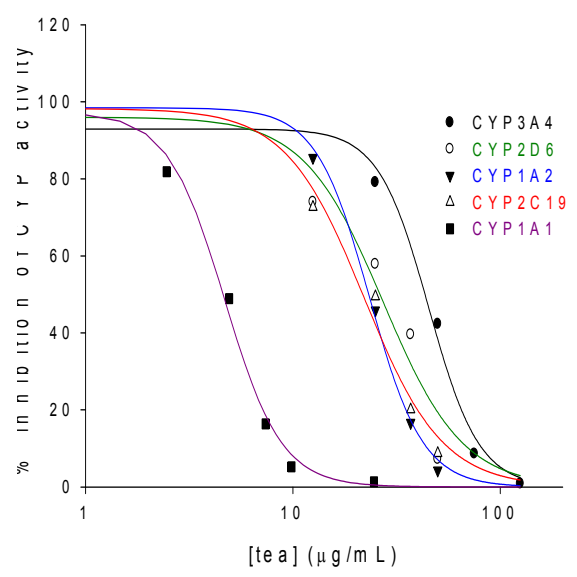

B

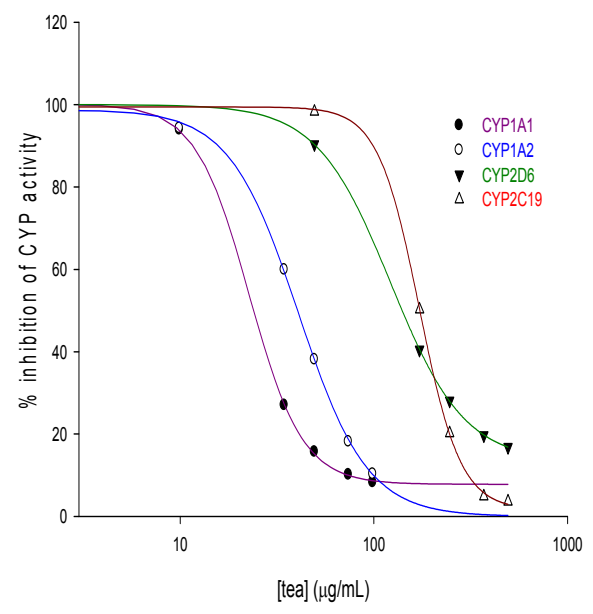

D

Fig. 3. Inhibition of CYP activity by medicinal plant infusions.

\subsection{Identification of active ingredients}

Due to the potency displayed against the activities of CYP450 enzymes, Psidium guajava was selected for further characterization. Preliminary separation of the freeze-dried extract of Psidium guajava by reverse phase HPLC (see Fig.4) revealed several resolved peaks and LCMS analysis at the same time and the results are summarized in Table 3. Two peaks were identified as quercetin and hyperin whose structures are shown in Fig.5 and these displayed 
$50 \%$ inhibition against the activity of CYP2D6 enzymes as shown in Fig.6. Previously modelled active site of CYP1A1 with bound quassin is displayed in Fig.7 where key residues in the enzyme are identified; Asp313, Thr11, Ser124, Phe123, Ile386 and Leu496 in the interaction between quassin and neoquassin.

Inhibition of CYP activity by Rhytidophyllum tomentosa infusion (A); Psidium guajava (B); Momordica charantia (C); and Symphytium officinale (D). Different volumes of reconstituted freeze-dried infusion were added to the incubation mixture, along with the CYP isoform, substrate, and 6GPDH, and monitored fluorometrically over time, as described in Materials and Methods. Control enzyme activity (mean \pm SEM) for CYP3A4, CYP1A1, CYP2D6, CYP1A2, CYP2C19, and CYP2C9 was $0.147 \pm 0.037,0.907 \pm 0.095,0.005 \pm 0.000,1.45 \pm 0.04$, $0.054 \pm 0.016$, and $0.057 \pm 0.004 \mu \mathrm{M} / \mathrm{min} / \mathrm{pmol}$ of CYP, respectively. Curves for CYP2D6 and CYP1A2 in for Memordica charantia (C) and for CYP3A4 in by Symphytium officinale (D) were not included because their $\mathrm{IC}_{50}$ values exceeded $200 \mu \mathrm{g} / \mathrm{mL}$.

\begin{tabular}{|c|c|c|c|c|c|}
\hline \multirow[t]{2}{*}{ Isoform } & \multicolumn{5}{|c|}{$\mathrm{IC}_{50}(\mu \mathrm{g} / \mathrm{mL})$} \\
\hline & $\begin{array}{l}\text { Rhytidophyllum } \\
\text { tomentosa }\end{array}$ & $\begin{array}{l}\text { Psidium } \\
\text { guajava }\end{array}$ & $\begin{array}{l}\text { Momordica } \\
\text { charantia }\end{array}$ & $\begin{array}{l}\text { Symphytium } \\
\text { officinale }\end{array}$ & $\begin{array}{l}\text { Picrasma } \\
\text { excelsa* }\end{array}$ \\
\hline CYP1A1 & 10.2 & 4.9 & 137.1 & 24.0 & 15.0 \\
\hline CYP1A2 & 28.3 & 24.0 & $>200.0$ & 40.3 & 19.1 \\
\hline CYP2D6 & 158.0 & 26.3 & $>200.0$ & 127.9 & $>200$ \\
\hline CYP2C19 & 93.8 & 23.3 & 91.0 & 172.7 & 199.9 \\
\hline CYP3A4 & 178.1 & 48.7 & 82.3 & $>200.0$ & 122.8 \\
\hline
\end{tabular}

*Values for Picrasma excelsa were obtained from Shields et al, 2008.

Table 3. Summary of $\mathrm{IC}_{50}$ values obtained for the extracts from Fig. 2

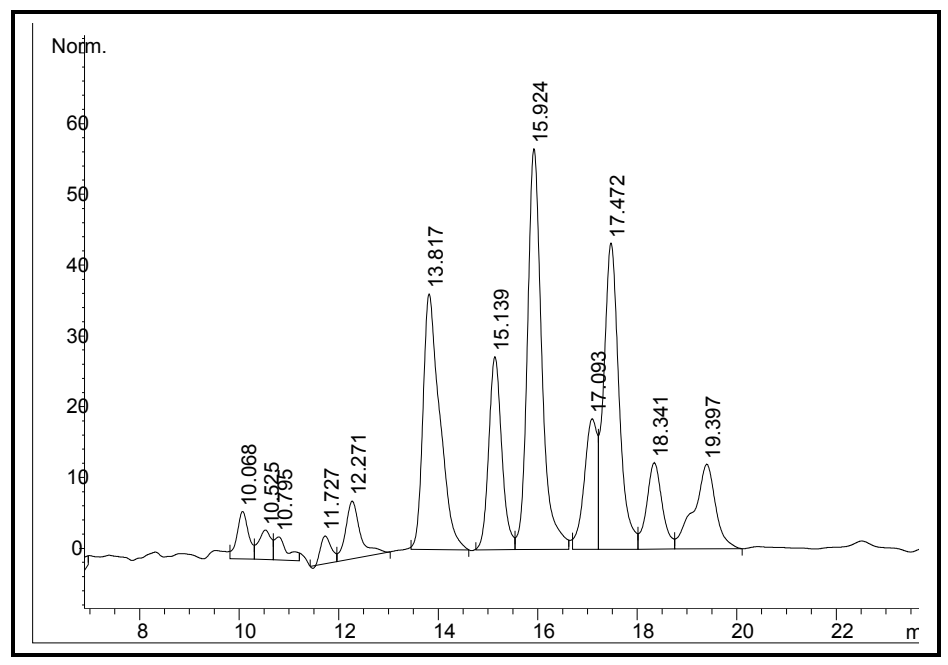

Fig. 4. HPLC profile of Psidium guajava extract 
<smiles>O=c1c(O)c(-c2ccc(O)c(O)c2)oc2cc(O)cc(O)c12</smiles>

Quercetin<smiles>O=c1c(OC2O[C@H](CO)[C@@H](O)[C@H](O)[C@H]2O)c(-c2ccc(O)c(O)c2)oc2cc(O)cc(O)c12</smiles>

Hyperin

Fig. 5. Structures of quercetin and hyperin (quercetin-3-D-galactoside).

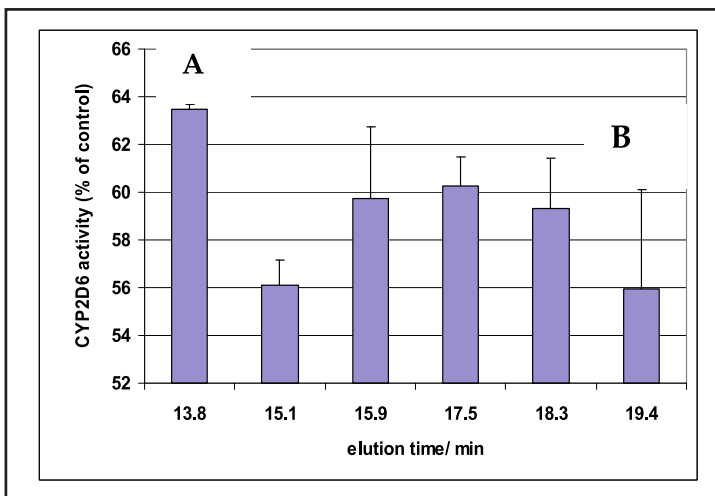<smiles>O=c1c(OC2O[C@H](CO)[C@@H](O)[C@H](O)[C@H]2O)c(-c2ccc(O)c(O)c2)oc2cc(O)cc(O)c12</smiles><smiles>O=c1c(O)c(-c2ccc(O)c(O)c2)oc2cc(O)cc(O)c12</smiles>

Fig. 6. HPLC profile of Psidium guajava (adapted from Shields et al., 2009). 


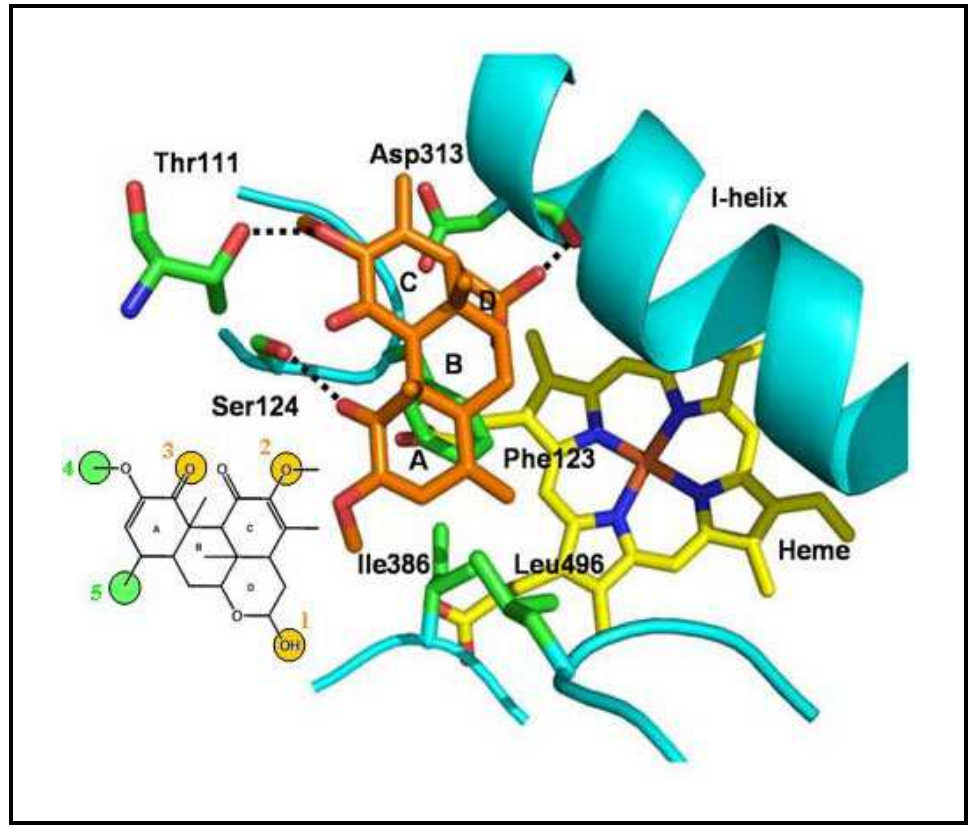

Fig. 7. Interaction of quassinoids with CYP1A1

\section{Discussion}

Cytochrome P450 enzymes have been of particular interest in the field of drug discovery for numerous reasons including the involvement of these enzymes in the metabolism of over $95 \%$ of the drugs on the market and the potential of drug-drug interaction through metabolism. CYP1 family which is under the regulation of the aryl hydrocarbon receptor have been extensively researched and implicated in drug resistance as well as carcinogenesis. CYP1B1 in particular, found in elevated levels in cancer tissues such as those in colon is thought to provide a novel pathway for drug discovery and optimisation for cancer treatment. Inhibitors of the activities of CYP1 enzymes are now accepted as potential chemoprotectants by preventing the activation of polycyclic aromatic hydrocarbons such as benzo-a-pyrene. Catalysed by CYP1A1 and CYP1B1, metabolites of this pro-carcinogen, (+)-anti-benzo[a]pyrene-trans-7,8-dihydrodiol-9,10-epoxide (anti$\mathrm{BPDE})$ and that 3-hydroxybenzo [a]pyrene $(3 \mathrm{HBaP})$ have been shown to bind to DNA predominantly at the $\mathrm{N}^{2}$-position of guanine to produce $\mathrm{N}^{2}$-guanine lesions, benzo-apyrene 7,8-diol-9,10-epoxide-N2-deoxyguanosine (BPDE-N2-dG) adduct (King et al., 1976). Thus inhibitors of CYP1 enzymes hold the potential to prevent the formation of such damaging precursors that initiate malignant cancers of the breast, colon, lung and urothelium among others.

In this chapter we highlight the potential of a few natural products abundant in the Caribbean: chromene amides isolated from Amyris plumieri, quassinoids isolated from Picrasma excelsa, anhydrosorbifolin isolated from Spathelia sorbifolia and chroman 6 isolated 
from Peperomia amplexicaulis. We also report for the first time bioactive screening of CYP enzymes in the presence of five aqueous infusions of popularly used herbs; Rhytidophyllum tomentosa, Psidium guajava, Symphytium officinale, Momordica charantia and Picrasma excelsa.

Potent and selective inhibition of the CYP1 enzymes were found amongst the investigated natural compounds in particular chromene amides and quassinoids. CA1 displayed potent inhibition against the activity of CYP1A1, with a $\mathrm{K}_{\mathrm{i}}$ of $0.37 \mu \mathrm{M}$ and an $\mathrm{IC}_{50}$ value of $1.31 \mu \mathrm{M}$ while quassin inhibited this enzyme with an $\mathrm{IC}_{50}$ value of $9.2 \mu \mathrm{M}$ and $\mathrm{K}_{\mathrm{i}}$ of $10.8 \mu \mathrm{M}$ with selectivity extended throughout all CYP enzymes investigated except CYP2C19 for CA1. The degree of potency and selectivity with which both compounds inhibited this enzyme warrants further research as possible chemoprotectants. Previously known and studied natural compounds deemed to possess chemoprotective properties due to their ability to inhibit CYP1A1 include; quercetin ( $\mathrm{IC}_{50}=1.36 \mu \mathrm{M}$, Leung et al., 2007), curcumin $\left(\mathrm{IC}_{50}=20 \mu \mathrm{M}\right)$, demethoxycurcumin $\left(\mathrm{IC}_{50}=21 \mu \mathrm{M}\right)$, $\varepsilon$-viniferin $\left(\mathrm{IC}_{50}=1 \mu \mathrm{M}\right)$, resveratrol $\left(\mathrm{IC}_{50}=30 \mu \mathrm{M}\right)$, and sanguinarine $\left(K_{\mathrm{i}}=2 \mu \mathrm{M}\right)$. Both test compounds compare well with these known chemoprotectants and thus warrant further research.

Both CYPs 1A1 and 1A2 share approximately 70\% similarity in amino acid and the specificity with which inhibition targeted towards CYP1A1 activity is noticeable in the compounds CA1, CA3 and quassin. As such we unlocked the interaction between quassin and CYP1A1 in previous publication (Shields et al., 2009). One of the first active site models for CYP1A1 was demonstrated with quasin and important residues were highlighted; Asp313, Thr11, Ser124, Phe123, Ile386 and Leu496 as shown in Fig.7 as being critical for binding quassinoids.

CYP1B1 has been drawing keen interest for novel and anticancer therapeutics. Findings of the over-expression of CYP1B1 in many tumour tissues compared with normal surrounding cells, have led to the search for pro-drugs reliant on CYP1B1 metabolism for the conversion into cytotoxic therapeutics. Although the role of such over- expression is yet to be fully understood, it has been linked with drug resistance and in the promotion of cell survival (Martinez et al., 2008). The modification in the expression levels of CYP1B1 has been shown to modulate tumour progression (Castro et al., 2008) and thus specific inhibitors are expected to be of therapeutic/preventive benefit. Although the potency and the specificity of the chromene amides examined this chapter against CYP1B1 is not particularly high, structure-activity relations may guide towards chromene amides with putative improvement. Anhydrosorbifolin and chroman 6 displayed the most potency against this enzyme deeming further investigations worthwhile.

Little impact towards the CYP1 family was observed in the presence of CA2 which could be due to the isopropyl group on this chromene amide, compared with CA1. Even though the $\mathrm{K}_{\mathrm{i}}$ against CYP1A1 was increased (to $2.63 \mu \mathrm{M}$ ), the $\mathrm{IC}_{50}$ value remained more or less the same as CA1 $(1.63 \mu \mathrm{M})$, displayed moderate to low potency against CYPs 1A2 and 1B1. The structural change made to CA2 was more significant in binding CYP2D6 as the inhibition dropped over a 100 times $\left(\mathrm{IC}_{50}=360 \mu \mathrm{M}\right.$ for $\mathrm{CA} 2 \mathrm{vs} 2 \mu \mathrm{M}$ for CA1). Hence, CA2 displayed characteristics of a useful molecular probe where all significant drug metabolizing enzymes can be inhibited except for the activity of CYP2D6. Chain elongation and the loss of branching in the n-propyl end unit to form CA3, have a 
dramatic impact on the affinity to CYP1A2 and CYP1B1. The inhibition potency dropped 6 folds against CYP1A2 (from $32.8 \mu \mathrm{M}$ for CA1 to $189.8 \mu \mathrm{M}$ for CA3) and 10 folds against CYP1B1 (from15.4 $\mu \mathrm{M}$ to $179.3 \mu \mathrm{M}$ ). Thus, CA3 appears to show increased selectivity in its inhibition against CYP1A1. Exploring other side groups as well as shifting the position of the existing side groups can be explored in hopes of increasing the potency of CAs towards the activity of CYP1B1

There is a large consumption of natural medicines alone and concurrently with prescription medicines in the Caribbean, as in many parts of the world. This is confirmed in a recent pilot study done in which $80 \%$ of prescription medicine consumers also take natural remedies (Delgoda et al., 2004; Picking et al., 2011). Also, adverse drug reactions (ADRs) accumulates to over 2 million per year in the United States alone (Gurwitz et al., 2000), therefore, the ability to predict drug interactions involving the CYP enzymes has become a key component of the drug discovery process (Forti and Wahlstrom, 2008). Providing the FDA with the metabolic profile of a new drug entity with CYP enzymes is the first step towards avoiding adverse reactions (Delgoda and Westlake, 2004). Known drug -herb interactions with clinical impact include grapefruit juice with felopidium, tricyclic anti depressants which is medicated through CYP3A4 inhibition.

We report for the first time hot water infusions of Rhytidophyllum tomentosa, Psidium guajava, Symphytium officinale, Momordica charantia in comparison with reported Picrasma excelsa being tested against CYP enzymes activity. The greatest potency was observed in the presence of Psidium guajava that inhibited CYP1A1 with an $\mathrm{IC}_{50}$ of $4.9 \mu \mathrm{g} / \mathrm{mL}$. All of the infusions are commonly consumed, be it, the fruit or as teas. With the high levels of polypharmacy practise that exist among Caribbean people and the world, having a metabolic profile on teas or commonly consumed plants become of grave importance. Results displayed in Table 3 point to is minimal risk through CYP mediated drug interactions as the teas weakly inhibited the main drug metabolising enzymes. Because, the activity of Psidium guajava towards CYP1A1 was the most potent we further evaluated the identification of the active ingredients that could be responsible for the observed bioactivity towards the CYP1A1 activity. The active ingredients were found to be quercetin and hyperin (see Figs. 4 \& 5), compounds known as inhibitors of CYP enzymes, where quercetin isolated from St. John's Wort has been previoulsy shown to inhibit activities of CYPs 1A2, 2C19 and CYP2D6 with $\mathrm{IC}_{50} \mathrm{~s}$ of $3.87 \mu \mathrm{M}, 6.23 \mu \mathrm{M}$ and $20.99 \mu \mathrm{M}$ respectively; while hyperforin isolated from Ginko biloba shown to inhibit the activity of CYP3A4 with an $\mathrm{IC}_{50}$ of 4.30 $\mu \mathrm{M}$ (Moltke et al., 2004; Zou et al., 2002). Inhibitions against the CYP enzymes appear to be between moderate and weak which confirms data in our lab, thus evoking moderate concern for potential interactions with co-medicated pharmaceuticals through CYP mediated metabolism.

\section{Conclusion}

Review of compounds that have potent and selective inhibitory properties against the activities of CYP1 family in particular CYPs 1A1 and 1B1 aid in identification of useful chemoprotectors. CA1 and quassin warrant further research because they were both potent against the activity of CYP1A1 while anhydrosorbifolin and chroma 6 targeted 
CYP1B1. In vitro and in silico models as demonstrated for the first time in this chapter are useful tools in the process of drug development to approximate the risk of drug interactions and in the process of target improvement of key enzymes in chemoprevention. In particular, for herbal remedies they confer useful models for evaluating the risks of adverse effects arising from interactions with co-administered prescription medicines, for which drug-interaction information is not mandated by the regulatory agencies. Once the initial risk is estimated, clinical drug-interaction studies can be launched, thus providing a cost-effective sieving process prior to embarking on rigorous and expensive investigations.

\section{Acknowledgments}

We are grateful to the International Foundation for Science (IFS), Sweden, the University of the West Indies post graduate fund, the Forestry Conservation fund and the Luther Speare Scholarship for financial support. We are also grateful to Professor Helen Jacobs for provision of select natural products.

\section{References}

Badal, S.; Williams, S. G. Huang, G. Francis, S. Vedantam, P. Dunbar, O. Jacobs, H. Tzeng, J. Gangemi J. and Delgoda, R. (2011). Cytochrome P450 1 enzyme inhibition and anticancer potential of chromene amides from Amyris plumieri, Fitoterapia. Vol.82 pp. 230-236.

Cassady, J.M.; Baird, W.M. Chang, C.J. (1990). Natural Products as a Source of Potential Cancer Chemotherapeutic and Chemopreventive Agents. Journal of natural products. Vol.53 pp 23-41.

Castro, D.J.; Baird, W.M. Pereira, C.B. Giovanni, J. Löhr, C. Fischer, K. Yu, Z. Gonzalez, F.J. Krueger, S.K. Williams D.E. (2008). Fetal mouse cyp1b1 and transplacental carcinogenesis from maternal exposure to Dibenzo[a,l]pyrene. Cancer Prev Res, Vol.1 pp. 128-34.

Chabner, B.; (1991). Anti-cancer drugs. Principles and Practice, $4^{\text {th }}$ Edition. Philadelphia, Lippincott pp. 325-417

Chang, T.; Chen, J.S. Benetton, S. (2002). In Vitro Effect of Standardized Ginseng Extracts and Individual Ginsenosides on the Catalytic Activity of Human CYP1A1, CYP1A2, and CYP1B1. Drug Metab. Dispo,s Vol.30 pp. 378-384.

Chang, S.; Johnston Jr, P. Frokjaer-Jensen, C. Lockery, S. and Hobert, O. (2004). Hobert, MicroRNAs act sequentially and asymmetrically to control chemosensory laterality in the nematode. Nature, Vol.430 pp.785-789.

Chen, Z.H.; Hurh, Y.J. Na, H.K. Kim, J.H., Chun, Y.J. Kim, D.H. Kang, K.S. Cho, M.H. Surh, Y.J. (2004). Resveratrol inhibits TCDD-induced expression of CYP1A1 and CYP1B1 and catechol estrogen-mediated oxidative DNA damage in cultured human mammary epithelial cells. Carcinogenesis, Vol. 25 pp. 2005-2013.

Ciolino, H.; Daschner, P. and Yeh, G. (1998). Resveratrol inhibits transcription of CYP1A1 in vitro by preventing activation of the aryl hydrocarbon receptor. Cancer Res Vol.58 pp. 5707-5712. 
Delgoda, R.; and Westlake, A. (2004). Herbal Interactions involving Cytochrome P450 enzymes. Toxicol Rev, Vol. 23 pp. 239-249.

Delgoda, R.; Ellington, C. Barrett, S. Gordon, N. Clarke, N. Younger, N. (2004). The practice of polypharmacy involving herbal and prescription medicines in the treatment of diabetes mellitus, hypertension and gastrointestinal disorders in Jamaica. West Indian Medical Journal, Vol.53 pp. 400-404.

Delgoda, R.; Younger, N. Barrett, C. Braithwaite, J. and Davis, D. (2010). The prevalence of herbs use in conjunction with conventional medicines in Jamaica. Complementary Therapies in Medicine, Vol.18 pp. 13-20.

Forti, R.; and Wahlstrom, J. (2008). CYP2C19 inhibition: The impact of substrate probe selection on in vitro inhibition profiles. Drug metabolism and disposition, Vol.36 pp. 523-528.

Fuente, G.; Reina, M. and Timon, I. (1991). Chromene amides from Amyris texana. Phytochemistry, Vol. 30 pp. 2677-2684.

Guengerich, F.P; (1997) Role of cytochrome P450 enzymes in drug-drug interactions. Adv Pharmacol, Vol. 43 pp. 7-35.

Guengerich, F.P; (2003). Cytochromes P450, drugs, and diseases. Mol Interv, Vol. 3(4) pp. 194-204.

Guengerich, F.; and Shimada, T. (1991). Oxidation of toxic and carcinogenic chemicals by human cytochrome P-450 enzymes. Chem. Res. Toxicol, Vol. 4 pp. 391-407.

Gurwitz, J.; Field, T. Avorn, J. McCormick, D. Jain, S. Eckler, M. Benser, M. Edmondson, A. and Bates, D. (2000). Incidence and preventability of adverse drug events in nursing homes. Am J Med, Vol. 109 pp. 87-94.

Hartwell, J.; (1968). Plants used against cancer: a survey. Loydia, Vol.31 pp.171-179.

Ioannides, C.; (2002). Pharmacokinetic interactions between herbal remedies and medicinal drugs. Xenobiotica, Vol. 32 pp. 451-478. Read More: http://informahealthcare.com/doi/abs/10.1080/00498250210124147

King, H.W.S.; Osbourne, M.R. Beland, F.A. Harvey, R.G. and Brookes, P. (1976). (+)-7a,8 8 Dihydroxy-9 $\beta, 10 \beta$-epoxy-7,8,9,10-tetrahydrobenzo[a ]-pyrene is an intermediate in the metabolism and binding to DNA of benzo[a]pyrene. Proc. Nati. Acad. Sci., Vol. 73 pp. 2679-2681.

Klingenberg, M,; (1958). Pigments of rat liver microsome. Archives of biochemistry and biophysics, Vol.75 pp. 376-386.

Landi, M.; Sinha, R. Lang, N. and Kadlubar, F. (1999). Human cytochrome P4501A2. IARC Sci Publ, Vol.148 pp.173-195.

Leung, H.Y.; Wang, Y., Chan, H.Y., Leung, L.K. (2007) Developing a high throughput system for the screening of cytochrome P450 1A1- Inhibitory polyphenols. Toxicol in Vitro, Vol.21 pp. $996-1002$

Martinez, V.; O' Connor, R. Liang, Y. and Clynes, M. (2008). CYP1B1 expression is induced by docetaxel: effect on cell vialbility and drug resistance. British journal of cancer, Vol.98 pp. 564-570.

Meyer, B.; Pray-Grant, Vanden Heuvel, J. and Perdew, G (1998). Hepatitis B virus X-associated protein 2 is a subunit of the unliganded aryl hydrocarbon receptor core complex and exhibits transcriptional enhancer activity. Mol Cell Biol, Vol.18 pp. 978-988. 
Mitchell, S.; and Ahmad, M. (2006). A Review of Medicinal Plant Research at the University of the West Indies, Jamaica, 1948-2001. West Indies Medical Journal, Vol. 55 pp. 243-269.

Moltke, L.L.; Weemhoff, J.L. Bedir, E. Khan, I.A. Harmatz, J.S. Goldman, P. Greenblatt, D.J. (2004). Inhibition of human cytochromes P450 by components of Ginkgo biloba. Journal of Pharm. And Pharmacol, Vol.56 pp. 1039-1044.

Mota, J.d.S.; Leite, A.C. Junior, M.B. Lopez, S.N. Ambrosio, D.L. Passerini, G.D. Kato, M.J. Bolzani, V.d.D. Cicarelli, B.R.M.. Furla, M. (2009). In vitro Trypanocidal Activity of Phenolic Derivatives from Peperomia obtusifolia. Planta Med, Vol. 75 pp. 620-623

Nelson, D.; (2009). "Cytochrome P450." Available at <http://drnelson.utmem.edu/CytochromeP450.html>.

Nelson, D.R.; Koymans, L. Kamataki, T. Stegeman, J.J. Feyereisen, R. Waxman, D.J. Waterman, M.R. Gotoh, O. Coon, M.J. Estabrook, R,W. Gunsalus, I.C. Nebert, D.W. (1996). P450 superfamily: update on new sequences, gene mapping, accession numbers and nomenclature. Pharmacogenetics and genenomics, Vol.6 pp. 1-42.

Nelson, D.; and Nebert, D.(2011). Cytochrome P450 gene (CYP) superfamily. Encyclopedia of Life Sciences (ELS) Chichester, John Wiley \& Sons, Ltd: pp. 1-13.

Nebert, D.; Adesnik, M. Coon, M. Estabrook, R. Gonzalez, F. Guengerich, F. Gunsalus, I. Johnson, E. Kemper, B. Levin W. and et al. (1987). The P450 gene superfamily: recommended nomenclature. DNA, Vol. 6 pp. 1-11.

Osborne, M.R.; Brookes, P. Baland, F.A.,Harvey, R.G . (1976). The reaction of $( \pm)-7 \mathrm{a}, 8 \beta-$ dihydroxy-9 $\beta, 10 \beta$-epoxy-7,8,9,10-tetrahydrobenzo(a)pyrene with dna. International journal of cancer, Vol.18 pp. 362-368.

Picking, D.; Younger, N. Mitchell, S. Delgoda, R. (2011). The prevalence of herbal medicine home use and concomitant use with pharmaceutical medicines in Jamaica. Journal of Ethnopharmacology, Vol.137 pp. 305-311.

Shields, M..; Niazi, U. Badal, S. Yee, T. Sutcliffe, M. and Delgoda, R. (2009). Inhibition of CYP1A1 by Quassinoids found in Picrasma excelsa. Planta Medica, Vol.75 pp. 137-141.

Shimada, T.; Yun, C. Yamazaki, H. Gautier, J. Beaune, P. Guengerich, F. (1992). Characterization of human lung microsomal cytochrome P-450 1A1 and its role in the oxidation of chemical carcinogens. Mol. Pharmacol. Vol.41 pp. 586-864.

Shimada, T.; Yamazaki, H. Mimura, M. Inui, Y. and Guengerich, F. (1994b). Interindividual variations in human liver cytochrome P450 enzymes involved in the oxidation of drugs, carcinogens, and toxic chemicals: studies with liver microsomes of 30 Japanese and 30 Caucasians. Pharmacol. Exp. Ther, Vol.270 pp. 414-423.

Shukla, R.; Liu, T. Geacintov, N. Loechler, E. (1997). The Major, N2-dG Adduct of (+)-antiB[a]PDE Shows a Dramatically Different Mutagenic Specificity (Predominantly, G $\rightarrow$ A) in a 5'-CGT-3' Sequence Context. Biochemistry, Vol. 36 pp. 10256-10261.

Stoner, G.; Morse, M. and Kelloff, G. (1997). Perspectives in cancer chemoprevention." Environ Health Perspect, Vol.105 pp. 945-954.

Treasure, J.; (2000). Herbal Pharmacokinetics: A practitioner update with reference to St. Johns Wort (Hypericum perforatum) Herb-Drug Interactions. MNIMH Vol.1.4 pp. 6-7. 
Zou, L.; Hrakey, M.R. Henderson, G.L. (2002). Effects of herbal components on cDNAexpressed cytochrome P450 enzyme catalytic activity. Life Sciences, Vol.71 pp. 1579-1589.

Yarbro, JW.; (1992). The scientific basis of cancer chemotherapy, In: Perry MG (Ed.): Chemotherapy source book (Ed3). Baltimore. Williams and Wilkins 2001. pp.3-18. 


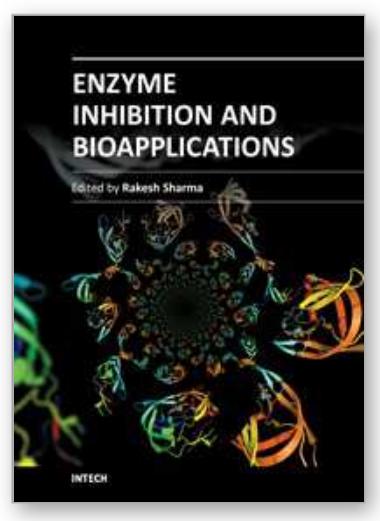

\author{
Enzyme Inhibition and Bioapplications \\ Edited by Prof. Rakesh Sharma
}

ISBN 978-953-51-0585-5

Hard cover, 314 pages

Publisher InTech

Published online 09, May, 2012

Published in print edition May, 2012

Enzyme Inhibition and Bioapplications is a concise book on applied methods of enzymes used in drug testing. The present volume will serve the purpose of applied drug evaluation methods in research projects, as well as relatively experienced enzyme scientists who might wish to develop their experiments further. Chapters are arranged in the order of basic concepts of enzyme inhibition and physiological basis of cytochromes followed by new concepts of applied drug therapy; reliability analysis; and new enzyme applications from mechanistic point of view.

\title{
How to reference
}

In order to correctly reference this scholarly work, feel free to copy and paste the following:

Simone Badal, Mario Shields and Rupika Delgoda (2012). Cytochrome P450 Enzyme Inhibitors from Nature, Enzyme Inhibition and Bioapplications, Prof. Rakesh Sharma (Ed.), ISBN: 978-953-51-0585-5, InTech, Available from: http://www.intechopen.com/books/enzyme-inhibition-and-bioapplications/cytochrome-p450enzyme-inhibitors-from-nature

\section{INTECH}

open science | open minds

\section{InTech Europe}

University Campus STeP Ri

Slavka Krautzeka 83/A

51000 Rijeka, Croatia

Phone: +385 (51) 770447

Fax: +385 (51) 686166

www.intechopen.com

\section{InTech China}

Unit 405, Office Block, Hotel Equatorial Shanghai

No.65, Yan An Road (West), Shanghai, 200040, China

中国上海市延安西路65号上海国际贵都大饭店办公楼 405 单元

Phone: +86-21-62489820

Fax: +86-21-62489821 
(C) 2012 The Author(s). Licensee IntechOpen. This is an open access article distributed under the terms of the Creative Commons Attribution 3.0 License, which permits unrestricted use, distribution, and reproduction in any medium, provided the original work is properly cited. 